\title{
Current status of long-term antibiotic prophylaxis for urinary tract infections in children: An antibiotic stewardship challenge
}

\author{
Sarah S. Alsubaie ${ }^{1 \mathbb{( D}}$, Mazin A. Barry ${ }^{2}$ (i) \\ ${ }^{1}$ Pediatric Infectious Diseases Unit, Department of Pediatrics, King Saud University Medical City, College of Medicine, King Saud \\ University, Riyadh, Saudi Arabia \\ ${ }^{2}$ Infectious Diseases Unit, Department of Internal Medicine, King Saud University Medical City, College of Medicine, King Saud \\ University, Riyadh, Saudi Arabia
}

\begin{abstract}
Recurrent urinary tract infections (UTIS) in children are associated with development of pyelonephritis and renal scarring. Traditionally, continuous antibiotic prophylaxis (CAP) has been used to prevent recurrent UTI. Recent studies have challenged the efficacy of CAP for preventing renal scarring and have raised concerns about inducing bacterial resistance. This review focuses on studies published between January 2000 and April 2019 and evaluates the use of CAP in children for avoiding recurrent UTIs and renal scarring. A systematic literature search was carried out using the following search terms and related medical subject headings in the MEDLINE electronic database: 'urinary tract infection', 'antimicrobial/antibiotic prophylaxis', and 'children/pediatrics'. Randomized clinical trials (RCTs), original research articles, guidelines, systematic reviews, and meta-analyses describing antibiotic prophylaxis for UTIs were included. A total of 34 RCTs, 9 systematic reviews, and 3 guidelines describing antibiotic prophylaxis were included in this review. The efficacy of CAP for preventing recurrent UTI remains unclear due to non-generalizability of results obtained from suboptimally designed clinical trials. CAP has not been proven as beneficial for preventing new renal scarring in children. Additionally, CAP is associated with increased risk of multidrug resistant infections in children. No conclusive evidence can be drawn from the available clinical data to support routine use of CAP for prevention of renal scarring. Accumulation of evidence from additional well designed studies may result in different conclusions in the future. It is important to identify specific risks for recurrent UTI and ensuing renal injury to ensure more judicious use of CAP.
\end{abstract}

Keywords: Anti-bacterial agents, Antibiotic prophylaxis, Child, Pediatrics, Urinary tract infections

Received September 4, 2019; Revised October 15, 2019;

Accepted October 21, 2019

Edited by Eun Hui Bae, Chonnam National University, Gwangju, Republic of Korea

Correspondence: Sarah S. Alsubaie

Pediatric Infectious Diseases Unit, Department of Pediatrics, King Saud University Medical City, College of Medicine, King Saud University, PO Box 2925, Riyadh 11461, Saudi Arabia. E-mail: salsubaie@ksu.edu.sa

Copyright () 2019 by The Korean Society of Nephrology

(a) This is an open-access article distributed under the terms of the Creative Commons Attribution Non-Commercial License (http://creativecommons. org/licenses/by-nc-nd/4.0/), which permits unrestricted non-commercial use, distribution, and reproduction in any medium, provided the original work is properly cited.

\section{Introduction}

Urinary tract infections (UTIs), especially those limited to the lower urinary tract, are commonly reported in young febrile children. Especially in children with vesicoureteral reflux (VUR), UTI recurrence has been reported to be associated with development of pyelonephritis and renal scarring. These sequelae cause major concern for potential development of hypertension, chronic kidney disease, and possible growth impairment [1-3]. Thus, prevention of recurrent UTIs in children may help prevent subsequent chronic kidney damage. 
The incidence of UTIs in children varies with age, sex, circumcision status in males, race, ethnicity, and geographic location. In infants less than 1 year old, boys $(2.7 \%$ to $3.7 \%)$ are more prone to UTIs than girls $(0.7 \%$ to $2 \%)$. The sex-based difference in incidence is even more pronounced during the first 2 to 6 months, when uncircumcised boys are at 10 - to 20 -fold higher risk of developing a UTI. However, this trend is reversed for children in the age group of 1 to 7 years, when girls ( $0.9 \%$ to $8 \%$ ) are more prone to UTIs than boys $(0.2 \%$ to $2 \%)$ [4-7]. This reversal is attributed to shorter urethral length in girls, which enhances the chance for an ascending infection from the urethra to the bladder and upper urinary system [4].

Most UTIs in children are caused by Escherichia coli (detected in approximately $80 \%$ of cases), a microorganism that adheres to the inner lining of the urinary tract by its fimbriae (pili) and subsequently enters epithelial cells $[4,8]$. Other microorganisms that are generally encountered in children include Klebsiella pneumoniae, Enterobacter spp., Enterococcus spp., Staphylococcus spp., and Pseudomonas aeruginosa. These microorganisms are mostly found in recurrent UTIs and are more likely to cause renal scarring later in life compared to E. coli [8$10]$.

A retrospective study involving 262 children below one year of age with a first episode UTI revealed that about one third of the children had recurrent UTIs within 6 months of the primary infection. Concurrent Grade 3 to 5 VUR was identified as the most significant risk factor for recurrent UTI, and routine monthly follow-up was recommended for such children [11]. The risk of renal scarring is reported to increase with increased number of recurrent UTIs and higher VUR grade [12]. The National Institute for Health and Clinical Excellence summarized various predisposing factors for the development of recurrent UTIs and ensuing renal scarring. The factors include first UTI at 6 months or less, concurrent VUR (higher grades), male infant under 3 months or girl infant over 3 months, uncircumcised boy, anatomic abnormality in genitourinary tract, bladder instability, infrequent or dysfunctional voiding, lack of breastfeeding, fecal and perineal colonization, poor fluid intake, and constipation [13].

Continuous antibiotic prophylaxis (CAP) was initially introduced for prevention of recurrent UTIs without any controlled clinical study results $[14,15]$. Based on results of clinical studies, CAP was later proposed to avoid recurrent UTIs in children with an anatomical abnormality in the urinary system, prenatal hydronephrosis, and/or VUR. The practice was recommended by some treatment guidelines, although it was based on limited data [13]. Over time, the practice of CAP was further extended for preventing UTIs in children without complications such as VUR, hydronephrosis, or anatomical abnormalities. CAP overuse has started a debate about the usefulness of CAP in preventing renal scarring, which is the real concern of recurrent UTIs. Currently, available cumulative clinical evidence indicates that CAP confers negligible efficacy for prevention of renal scarring, the long-term sequelae and major concern of recurrent UTIs [16-18]. Additionally, over-prescription of CAP is linked with a higher incidence of acquired antibiotic resistance, increased medical and economic burden, disruption of natural bacterial flora, and unknown long-term adverse effects $[16,19,20]$. Unfortunately, controversies in the literature and inconsistencies in guidelines for the utilization of CAP to prevent subsequent UTIs have led to diverse medical practices. The current study presents a review of various studies published between January 2000 and April 2019 and evaluates CAP use in children for prevention of recurrent UTIs.

\section{Literature review}

The MEDLINE electronic database was searched for studies published between January 2000 to April 2019 using the following search terms: 'urinary tract infection' AND 'antimicrobial or antibiotic prophylaxis' AND 'children' OR 'pediatrics. For the purpose of this review, 'continuous antibiotic prophylaxis' was defined as daily antibiotic dosing for at least 6 months. Only studies written in English were included. Randomized clinical trials (RCTs), original research articles, guidelines, systematic reviews, meta-analyses, and reviews describing antibiotic prophylaxis for UTIs were included. Duplicate studies, studies carried out on adults ( $>18$ years), and case reports were excluded. Abstracts for all filtered publications were reviewed by the authors of this study to remove irrelevant publications. Full-text PDFs for all relevant publications were retrieved and reviewed by the authors. A total of 34 RCTs, 9 systematic reviews, and 3 guidelines describing antibiotic prophylaxis for UTIs were reviewed 
(Fig. 1). Additional references were identified from the bibliography of selected relevant publications. Information from related articles was organized into several key areas identified by consensus among the authors.

A forest plot was constructed from included RCTs. The frequency of UTI events in the antibiotic prophylaxis group versus those with no prophylaxis were extracted from each individual study. Effect estimates were computed as risk ratios (RRs) and their respective 95\% confidence intervals (CIs). Statistical heterogeneity between studies was assessed using a $\mathrm{I}^{2}$ test, where heterogeneity was considered significant at $\mathrm{I}^{2}>50 \%$. A random-effects model was applied when there was significant heterogeneity. Statistical analysis was performed using RevMan software 5.3.5.

\section{Microbial resistance in UTIs}

The major issue with overuse of antibiotic prophylaxis for preventing possible future recurrent infections is the advent of antibiotic-resistant strains of microorganisms. The proportion of such antibiotic-resistant strains has progressively increased in recent years, even in children without any significant health-related risk factors, due to overuse of broad-spectrum antibiotics to prevent future infections $[19,20]$. The emergence of multidrug-resistant bacteria such as extended-spectrum beta-lactamase (ESBL) producing E. coli has made management of UTIs even more challenging for medical practitioners, microbiologists, and pharmacists. Genetic information needed for production of ESBL enzymes can be transferred be- tween bacterial strains via plasmids. ESBL-producing bacteria can hydrolyze various broad-spectrum antibiotics, such as penicillins, cephalosporins, and monobactams, which become ineffective against such bacterial strains. This leaves very few options for treatment.

Various clinical research studies have evaluated the efficacy of CAP for prevention of recurrent UTIs in children. Studies found that CAP has limited efficacy and is associated with an increased risk of infections with antibiotic-resistant bacterial strains [21-23]. Several risk factors have been linked with the emergence of antibiotic-resistant bacterial strains in children with recurrent UTIs. The prevalence of antibiotic-resistant $E$. coli and other bacterial strains was significantly higher in children up to 2 years old compared with older children and adolescents. Moreover, the average antibiotic-resistance rate was significantly higher in boys than in girls for both inpatient and outpatient settings [24,25]. According to a surveillance study carried out on urinary tract isolates of E. coli, children receiving CAP had a 23 -fold increased risk of infection with $E$. coli resistant to trimethoprimsulfamethoxazole (TMP-SMX), the representative "firstline" agent used for CAP [26]. Similarly, results from other studies demonstrated the high emergence rate of antibiotic-resistant bacteria in children receiving CAP. The chance of infection with such antibiotic-resistant bacterial strains is particularly high in children who received CAP in the previous 6 months [26-30]. Less time for previous antibiotic exposure is associated with increased risk of developing antibiotic resistance. A group of researchers reported that exposure to amoxicillin with-

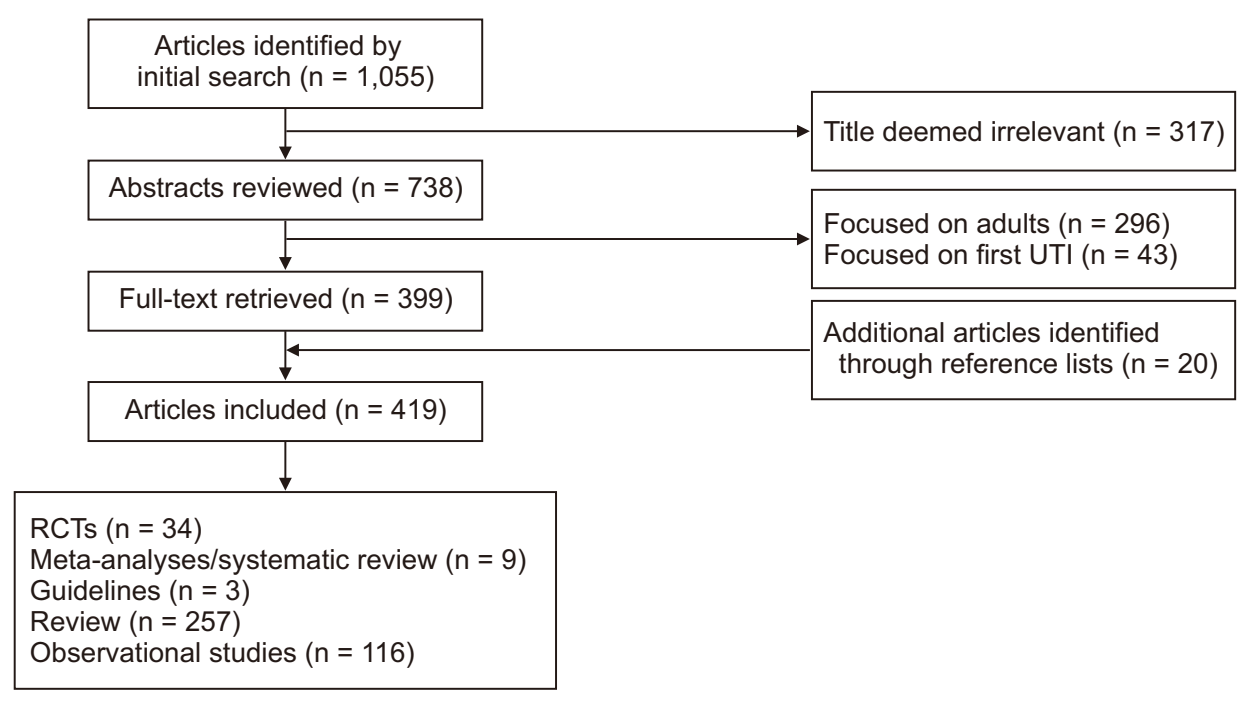

Figure 1. Flowchart depicting identification of studies, inclusion, and exclusion assessment for this review. RCTs, randomized clinical trials; UTI, urinary tract infection. 
in 30 days of a UTI was related with resistance to ampicillin, amoxicillin, and amoxicillin-clavulanate; exposure to amoxicillin within 30 to 60 days of a UTI was linked with resistance to ampicillin; exposure to amoxicillin within $>60$ days of a UTI was not associated with resistance to ampicillin [30]. Pre-existing neurological diseases, recent hospitalization (within 1 month), concurrent high-grade (greater than or equal to 3) VUR, and previous Klebsiella spp. infection were also identified as potential risk factors for development of UTIs caused by ESBL producing multidrug-resistant bacterial strains [31,32].

Breakthrough UTIs in children who were on CAP or who received CAP just before the UTI generally involve microorganisms that are resistant to both the antibiotic used for CAP as well as multiple other antibiotics, rendering them difficult to treat. The emergence of ESBLproducing bacteria is related to use of broad-spectrum antibiotics such as third-generation cephalosporins, amoxicillin, and quinolones for CAP, while the use of narrow-spectrum antibiotics such as TMP-SMX and nitrofurantoin for CAP are less likely to cause infection with antibiotic-resistant strains [26-28,33-35]. Thus, broadspectrum antibiotics should be avoided or limited for CAP in children with initial UTIs and concurrent anatomic abnormality in UTI. Cephalosporins, especially first-generation cephalosporins, are strong inducers of AmpC $\beta$-lactamases. Previous reports indicate that use of cephalosporin as a prophylactic antibiotic in children with VUR is strongly linked with the development of infection with ESBL-producing bacteria. Therefore, antibiotics should be judiciously prescribed after considering their potential to cause secondary infections with resistant bacterial strains.

A recent meta-analysis compared 1,299 children with recurrent UTIs and history of VUR who were receiving CAP to those receiving placebo/no treatment. Results conveyed that children on CAP were more likely to develop multidrug-resistant infections than those on placebo/no treatment (33\% versus $6 \%, P$ value $<0.001$; odds ratio [OR], 6.4; 95\% CI, 2.7-15.6). One in 21 cases of children on CAP developed a multidrug-resistant infection. Children on CAP were significantly more likely to receive broad-spectrum antibiotics to resolve their recurrent UTI compared to children not on CAP ( $68 \%$ versus $49 \%, P$ value $=0.004)$. Also, multidrug-resistant infections were related to longer hospitalization and a higher rate of de- veloping pyelonephritis. A group of researchers from California reported that the total rate of hospitalization for pyelonephritis surged by more than $80 \%$ between 1985 and 2005. This period also showed a 5-times increase in cases of multidrug-resistant infections. Thus, increased incidence of multidrug-resistant infections is proposed to play a role in the higher rate of hospitalization due to pyelonephritis [35].

To understand the dynamics of multidrug-resistant infections, it is important to study the geographic distribution of such infections over time. For this purpose, studies carried out in different countries were reviewed, including the United States, Canada, Belgium, France, Belgium, Turkey, Iran, Jordan, Korea, and Taiwan (Table 1) $[27-29,36-43]$. The patterns of multidrug resistance in pathogens causing UTIs among children of various age groups, sexes, and clinical conditions were studied [27-45]. Consistently across all geographic locations, recurrent UTIs caused by $E$. coli were considerably less common in children who received CAP compared with first episode UTIs. The overall incidence of UTIs and UTIs caused by ESBL-producing E. coli/other bacterial strains increased significantly over time in all geographic locations and all subgroups of pediatric patients. However, the antibiotic susceptibility pattern for UTIs across different geographic locations is slightly different. In Asia, studies of children with confirmed UTIs reported an ampicillin resistance rate of $66 \%$ to $82 \%$, whereas TMP-SMX resistance was $50 \%$ to $62 \%$ [31,36,40-42]. In the United States, most samples collected from children with suspected/confirmed UTI were sensitive to a firstgeneration cephalosporin, amoxicillin-clavulanate, and nitrofurantoin $[43,44]$. Efficient antibiotic stewardship and sensible selection of antibiotics based on identification of the causative organism (whether multidrugresistant or not) and on geographic location/local guidelines is paramount for treating UTIs in children whether or not they are receiving antibiotic prophylaxis.

\section{Controversy regarding CAP}

Current literature suggests that controversy remains among results obtained from different studies on the efficacy of CAP in preventing recurrent UTIs in children. Some studies suggest that CAP prevents recurrent UTIs in children who are prone to recurrent UTIs. Conversely, 
Table 1. Studies analyzing uropathogen resistance rates and trends

\begin{tabular}{|c|c|c|c|c|}
\hline Study & Location (time frame) & Age group, number, and design & Uropathogen rate & Resistance rate \\
\hline $\begin{array}{l}\text { Vazouras et al } \\
\text { (2019) [43] }\end{array}$ & Greece (2010-2015) & $\begin{array}{l}<18 \text { yr, } 230 \text { inpatient, } \\
\text { retrospective }\end{array}$ & $\begin{array}{l}\text { Escherichia coli 79\%, } \\
\text { Klebsiella } 7 \%\end{array}$ & $\begin{array}{l}\text { E. coli: AMP 42\%, TMP-SMX } 26 \% \text {, } \\
\text { NIT 2.3\%; } \\
\text { Klebsiella: AMC 13\%, CXM 14\%. }\end{array}$ \\
\hline $\begin{array}{l}\text { Yoo et al (2019) } \\
{[42]}\end{array}$ & Korea (2012-2017) & $\begin{array}{l}<15 \mathrm{yr}, 550 \text { children, } \\
\text { retrospective }\end{array}$ & $\begin{array}{l}\text { E. coli } 77 \%(\mathrm{ESBL}+24 \%) \\
\quad \text { Klebsiella } 17 \%\end{array}$ & $\begin{array}{l}\text { E. coli: AMP } 77 \% \text {, AMC } 34 \% \text {, CTX } \\
27 \% \text {, NIT } 7.7 \% \text {, CIP } 24 \%\end{array}$ \\
\hline $\begin{array}{l}\text { Erol et al (2018) } \\
\text { [41] }\end{array}$ & Turkey (2009-2014) & $\begin{array}{l}<18 \mathrm{yr}, 6,515 \text { urine sample, } \\
\text { retrospective }\end{array}$ & $\begin{array}{l}\text { E. coli } 55 \% \text {, Proteus 19\%, } \\
\text { Klebsiella } 14 \%\end{array}$ & $\begin{array}{l}\text { E. coli: AMP 47\%-56\%, AMC 47\%- } \\
\text { 89\%, AMC 44\%-51\%, TMP-SMX } \\
\text { 45\%-56\%, NIT 5.3\%-15.2\%; } \\
\text { Proteus: AMP 56\%-93\%, AMC } \\
\text { 43\%-56\%, TMP-SMX 36\%-47\%, } \\
\text { AMC 13\%-24\%, NIT: 68\%-78\% }\end{array}$ \\
\hline $\begin{array}{l}\text { Wang et al (2018) } \\
\text { [40] }\end{array}$ & China (2013-2016) & $\begin{array}{l}1 \text { mo-12 yr, 2,316 children, } \\
\text { retrospective }\end{array}$ & $\begin{array}{l}\text { Enterococcus spp. 35\%, } \\
\text { E. coli } 22 \% \text {, } \\
\text { Klebsiella } 7 \%\end{array}$ & $\begin{array}{l}\text { Enterococcus AMP 65\%, } \\
\text { E. coli: AMP 93\%, TMP-SMX 58\%, } \\
\text { levofloxacin 39\%; Klebsiella: AMP } \\
\text { 99\%, TMP-SMX 22\%, GEN 43\% }\end{array}$ \\
\hline $\begin{array}{l}\text { Saperston et al } \\
\text { (2014) [27] }\end{array}$ & United States (2009) & $\begin{array}{l}<18 \text { yrs, } 25,418 \text { outpa- } \\
\text { tients versus 5,560 } \\
\text { inpatients, retrospective } \\
\text { database analysis (195 } \\
\text { sites) }\end{array}$ & $\begin{array}{l}\text { E. coli } 79 \% \text { vs. } 54 \% \text {, } \\
\text { Enterococcus } 13 \% \text { vs. } \\
27 \%, \text { Klebsiella } 10 \% \text { vs. } \\
12 \%\end{array}$ & $\begin{array}{l}\text { E. coli resistance outpatients vs. } \\
\text { inpatients: AMP } 45 \% \text { vs. } 55 \% \text {, } \\
\text { TMP-SMX } 24 \% \text { vs. } 30 \% \text {, AMC } 5 \% \\
\text { vs. } 6 \%, \text { CIP } 5 \% \text { vs. } 9 \% \text {, CRO < } 1 \% \\
\text { vs. } 2 \%\end{array}$ \\
\hline $\begin{array}{r}\text { Garraffo et al } \\
(2014)[28]\end{array}$ & France (2011) & $\begin{array}{l}<12 \mathrm{yr}, 110 \text { children, } \\
\text { prospective (multicenter) }\end{array}$ & $\begin{array}{l}\text { E. coli } 78 \%, \text { Proteus } 9 \% \text {, } \\
\text { Enterococcus } 4 \%\end{array}$ & $\begin{array}{l}\text { E. coli resistance: } \geq 20 \% \text { (AMX, } \\
\text { TMP-SMX), <20\% (AMC, CIP, } \\
\text { GEN, NIT) }\end{array}$ \\
\hline $\begin{array}{l}\text { Sakran et al } \\
\text { (2015) [39] }\end{array}$ & Israel (2003-2009) & $\begin{array}{l}\text { < } 18 \text { yr, inpatients } 456 \text { first } \\
\text { episode vs } 106 \text { recurrent } \\
\text { UTIs, retrospective }\end{array}$ & $\begin{array}{l}\text { First vs recurrent } \\
\text { E. coli } 81 \% \text { vs. } 75 \% \text {, } \\
\text { Klebsiella } 6 \% \text { vs } 5 \% \text {, } \\
\text { Proteus } 4 \% \text { vs. } 5 \%, \\
\text { Pseudomonas } 2 \% \text { vs. } 8 \%\end{array}$ & $\begin{array}{l}\text { All uropathogen resistance (first vs. } \\
\text { recurrent) } \\
\geq 20 \% \text { (AMP, TMP/SMX), AMK } 8 \% \\
\text { vs. } 0 \% \text {; GEN } 3 \% \text { vs. } 5 \% \text {, CXM } 6 \% \\
\text { vs. } 17 \% \text {, NIT } 6 \% \text { vs. } 19 \%\end{array}$ \\
\hline $\begin{array}{l}\text { Mohammad-Jafari } \\
\text { et al (2012) [36] }\end{array}$ & $\operatorname{Iran}(2006-2009)$ & $\begin{array}{l}1 \text { wk-12 yr, 1,439 urine } \\
\text { samples, retrospective }\end{array}$ & $\begin{array}{l}\text { E. coli } 60 \% \text {, Enterobacter } \\
\text { 17\%, Other GNB } \\
\text { (Klebsiella, Proteus, } \\
\text { Pseudomonas) } 21 \%\end{array}$ & $\begin{array}{l}\text { E. coli resistance trend: AMP } 77 \%- \\
80 \% \text {, CRO 10\%-20\%, GEN 6\%- } \\
26 \% \text {, AMK 0\%-20\%, Cefixime, } \\
2 \%-38 \% \text {, Nalidixic acid } 2 \%-16 \\
\% \text {, no change for CIP }\end{array}$ \\
\hline $\begin{array}{l}\text { Ismaili et al } \\
\text { (2011) [29] }\end{array}$ & Belgium (2006-2008) & $\begin{array}{l}<3 \text { mo, } 209 \text { infants } \\
\text { (inpatients), prospective }\end{array}$ & $\begin{array}{l}\text { E. coli } 88 \% \text {, Klebsiella 7\%, } \\
\text { Enterobacter } 2 \%\end{array}$ & $\begin{array}{l}\text { E. coli resistance: } \\
\geq 20 \% \text { (AMP, TMP-SMX), } \\
<20 \% \text { (AMK, NIT, 2nd and 3rd } \\
\text { generation cephalosporins) }\end{array}$ \\
\hline $\begin{array}{l}\text { Doré-Bergeron } \\
\text { et al (2009) [38] }\end{array}$ & Canada (2005-2007) & 1-3 mo, 103, retrospective & E. coli 85\%, Klebsiella 7\% & $\begin{array}{l}\text { All strain resistance: } \\
\text { GEN } 2 \% \text { (other resistance patterns } \\
\text { not discussed) }\end{array}$ \\
\hline $\begin{array}{l}\text { Al-Mardeni et al } \\
\text { (2009) [37] }\end{array}$ & Jordan (2006-2007) & $\begin{array}{l}<4 \text { yr, } 529 \text { children, } \\
\text { outpatients }\end{array}$ & $\begin{array}{l}\text { E. coli } 85 \% \text {, Proteus 39\%, } \\
\text { Klebsiella 35\%, } \\
\text { Citrobacter } 15 \%\end{array}$ & $\begin{array}{l}\text { Multidrug-resistant } E \text {. coli } 60 \% \text {; } \\
\text { resistance patterns of E. coli vs. } \\
\text { non-E. coli: AMP } 82 \% \text { vs. } 83 \% \text {, } \\
\text { TMP-SMX } 72 \% \text { vs. } 80 \% \text {, LEX } 37 \% \\
\text { vs. } 52 \% \text {, NIT } 21 \% \text { vs. } 71 \% \text {, CRO } \\
20 \% \text { vs. } 28 \%\end{array}$ \\
\hline
\end{tabular}

AMC, amoxicillin-clavulanate; AMK, amikacin; AMP, ampicillin; CIP, ciprofloxacin; CRO, ceftriaxone; CXM, cefuroxime; ESBL, extended-spectrum beta-lactamase; GEN, gentamicin; GNB, gram-negative bacilli; LEX, cephalexin; NIT, nitrofurantoin; TMP-SMX, trimethoprim-sulfamethoxazole; UTIs, urinary tract infections. 
other studies suggest no or minimal efficacy of CAP. Another issue associated with these studies was use of variable standards, which makes it difficult to generalize the obtained results to the normal population. For example, most studies involved a non-stringent definition of UTI, an inconsistent/not standardized specimen collection method for identification of causative pathogens, inconsistent time intervals for urine analysis and surveillance of urinary cultures, inclusion of only children with lower grade VUR, and exclusion of circumcised boys in all of these studies $[18,22,23,46-50]$. Thus, the results obtained from these clinical studies should not be generalized to the normal population across different geographic locations.

Table 2 summarizes outcomes of these clinical studies. Studies conducted from 2006 to 2008 did not reveal any efficacy of CAP for preventing recurrent UTI in children with or without low-grade VUR $[18,22,23,46-50]$. The study conducted by Roussey-Kesler et al [49] indicated some benefit of CAP in preventing recurrent UTI. Their study was limited to a specific population of boys who were 1 month to 3 years old and had grade III VUR. It is important to note that these studies involve certain limitations related to study design. These limitations include small sample size, absence of any placebo or active control arm, inconsistent methodology for sample collection, inclusion of children without VUR, and not using blinding to prevent bias. These studies also did not discriminate febrile UTIs from nonfebrile UTIs [23,4749]. The next two studies carried out by Craig et al [22] (Prevention of Recurrent Urinary Tract Infection in Children with Vesicoureteric Reflux and Normal Renal Tracts, PRIVENT) and Brandström et al [46] (Swedish reflux trial) included a placebo arm and an active control arm, respectively, to remove limitations of the study design to some extent. Results from the PRIVENT study revealed moderate efficacy of CAP for prevention of UTIs in predisposed children under 18 years (13\% versus $19 \%, P$ value $=0.02$; hazard ratio $[\mathrm{HR}], 0.61 ; 95 \% \mathrm{CI}, 0.40-0.93$ ), and the results were consistent among all subgroups studied. Results obtained from the Swedish reflux trial revealed the efficacy of CAP for preventing UTIs only in girls with VUR grade III or IV and less than 2 years of age $(19 \%$ versus $57 \%, P$ value $=0.0002)$. The PRIVENT trial overcome many shortcomings related to study design and sample collection methodology as it included a pla- cebo arm, employed blinded treatment, and involved a standardized sample collection method for diagnosis of UTIs. However, limitations of the PRIVENT trial were that it assumed UTIs did not occur in patients who did not have follow up. It did not consider compliance to CAP treatment and did not report the relationship between recurrence and concurrent VUR. It was estimated that to prevent one UTI, around 1 year of CAP treatment should be prescribed to 14 children [22].

Considering all aspects discussed above, the precise benefit of CAP for preventing UTIs in high-risk children remained controversial. This led to the Randomized Intervention for Children with Vesicoureteral Reflux (RIVUR) trial sponsored by the National Institute of Diabetes and Digestive and Kidney Diseases (NIDDK), which was designed to remove all limitations of the previous clinical studies. A total of 607 children with VUR who were confirmed to have their first or second febrile or symptomatic UTI were enrolled at 19 sites across the United States and were randomized to receive either CAP or matching placebo for 2 years. Results obtained from the RIVUR trial revealed that CAP reduced the risk of febrile or symptomatic recurrent UTI by $50 \%$ compared to placebo ( $13 \%$ versus $24 \%$; HR, $0.50 ; 95 \% \mathrm{CI}, 0.34-0.74)$. The efficacy of CAP increased progressively with time between the two groups. It was estimated that to prevent one febrile or symptomatic UTI, around 8 children would have to be treated with CAP for two years. Subgroup analysis of the RIVUR data revealed that CAP was most effective for preventing febrile or symptomatic UTIs in children who had concurrent bladder and bowel dysfunction (BBD) (HR, $0.21 ; 95 \% \mathrm{CI}, 0.08-0.58)$ compared to those without concurrent BBD (HR, 1.40; 95\% CI, 0.43-4.58) and in children with first febrile UTI (HR, 0.41; 95\% CI, 0.26-0.64) compared to first nonfebrile UTI (HR, 1.28; 95\% CI, 0.473.46) [50]. The results of the RIVUR trials were reanalyzed by another group of researchers via a risk classification system [51]. The high-risk groups consisted of uncircumcised boys with VUR, children with concurrent VUR and BBD, and children with Grade IV VUR. The efficacy of CAP was more pronounced in children at high risk of developing recurrent febrile or symptomatic UTI compared with children at low risk of developing recurrent febrile or symptomatic UTI. This reanalysis estimated that to prevent one febrile or symptomatic UTI, around 5 children in the high-risk group (compared with 18 chil- 


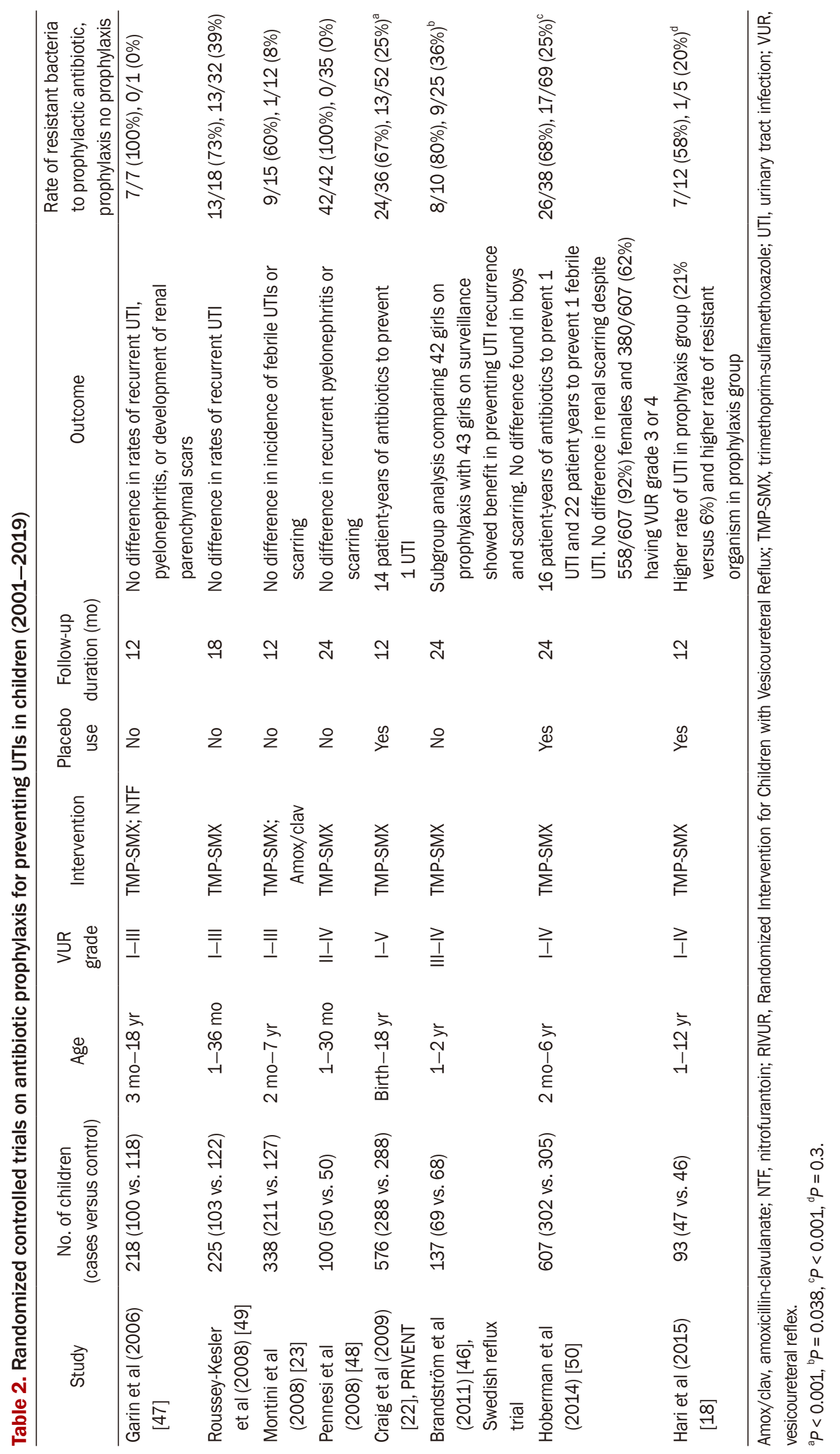




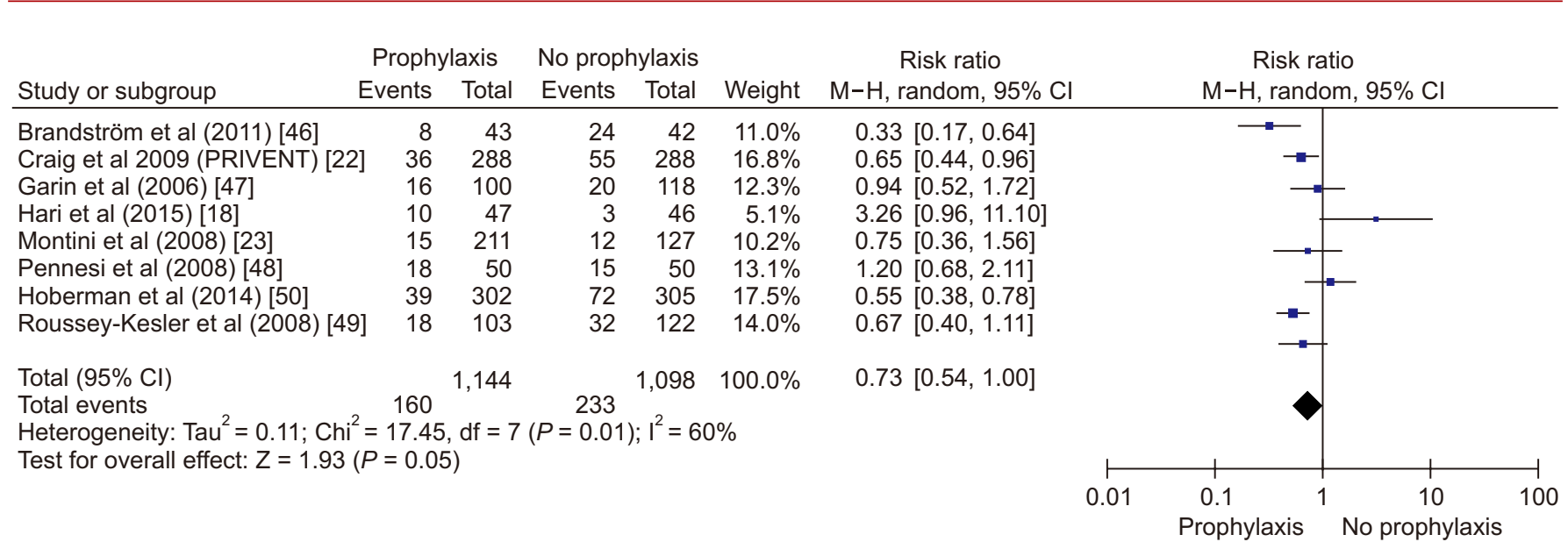

Figure 2. Forest plot depicting risk of urinary tract infections among children receiving prophylactic antibiotics versus those receiving placebo.

$\mathrm{Cl}$, confidence interval; $\mathrm{M}-\mathrm{H}$, Mantel-Haenszel test; PRIVENT, Prevention of Recurrent Urinary Tract Infection in Children with Vesicoureteric Reflux and Normal Renal Tracts; RIVUR, Randomized Intervention for Children with Vesicoureteral Reflux.

dren in the low-risk group) have to be treated with CAP for 2 years [51]. Hence, results obtained from the RIVUR trial can be utilized to identify children at high risk of developing recurrent febrile UTIs who will most benefit from CAP. This may help to avoid unnecessary antibiotic exposure to other children and reduce the emergence of antibiotic-resistant infections.

Though the RIVUR trial was successful in removing various limitations associated with previous RCTs, it also involved certain limitations. The most important limitation of the RIVUR trial was a skewed study population. About $92 \%$ of the RIVUR study population was girls, most (80.4\%) included children had low-grade (II to III) VUR, and the majority of them (91.3\%) had only one incidence of febrile UTI. Another limitation was the high adherence rate to study treatment owing to stringent follow-up compared with the real-world setting. In the RIVUR trial, around $77 \%$ of children received study treatment at least $75 \%$ of the time, and about $85 \%$ of children received study treatment at least $50 \%$ of the time [50]. However, another study that reviewed compliance in a similar population receiving a similar treatment reported a compliance rate of merely $40 \%$ [52]. These results raise concerns that the efficacy of CAP observed in RIVUR may not translate to the real world setting due to low adherence. Results obtained in another clinical study in India with a similar protocol to that of RIVUR produced opposite results for the efficacy of CAP compared with placebo in preventing recurrent UTIs $(21.3 \%$ versus $6.5 \%, P$ value $=0.02$; $\mathrm{HR}, 3.9$;
95\% CI, 1-14) [18]. These results further raise concerns regarding the use of RIVUR trial results in geographicallydiverse populations.

The pooled RCT results (Fig. 2) reveal that CAP was associated with $27 \%$ decrease in the odds of UTI (pooled RR 0.73) $[18,22,23,46-50]$. However, the forest plot showed significant heterogeneity between studies $\left(\mathrm{I}^{2}=63 \%, P\right.$ value $=0.008)[18,22,23,46-50]$. Of all included RCTs, not a single study was adequately powered to assess the effectiveness of CAP for preventing renal scarring [53]. Hence, we cannot conclude whether CAP is helpful in averting renal scarring in children at high risk of developing recurrent febrile UTIs.

\section{Systematic reviews and meta-analyses}

Systematic review and meta-analyses allow comparison of data among clinical studies with similar study populations and study arms. Table 3 summarizes various published systematic reviews and meta-analyses on the efficacy of CAP for preventing UTI in pediatric patients $[17,54-60]$. As discussed above for clinical studies, systematic reviews and meta-analyses conducted until 2010 also lacked placebo-controlled or active-controlled clinical data. Therefore, these studies provided unreliable, variable results on the efficacy of CAP in preventing recurrent UTIs [54-57]. Most of these studies highlight the need for high-quality, large scale, placebo-controlled, double-blind clinical trials for appropriate estimation 
Alsubaie and Barry. Long-term antibiotic prophylaxis for UTIs in children

Table 3. Systematic reviews and meta-analyses on efficacy of antibiotic prophylaxis for preventing urinary tract infection in pediatric patients

\begin{tabular}{|c|c|c|c|c|c|}
\hline Study & $\begin{array}{l}\text { Number of } \\
\text { studies (no. } \\
\text { of subjects) }\end{array}$ & $\begin{array}{l}\text { Antibiotic prophylaxis } \\
\text { recommended? }\end{array}$ & Outcome measure & $95 \% \mathrm{Cl}$ & Comments \\
\hline $\begin{array}{r}\text { Williams et al } \\
\text { (2001) [54] }\end{array}$ & $3(392)$ & Yes & RR: 0.31 & $0.10-1.00$ & $\begin{array}{l}\text { Antibiotics reduced risk of recurrent } \\
\text { UTI. Most included studies were } \\
\text { poorly designed with biases known to } \\
\text { overestimate true treatment effect. }\end{array}$ \\
\hline $\begin{array}{r}\text { Williams et al } \\
(2006) \text { [55] }\end{array}$ & $8(618)$ & Yes & RR: 0.44 & $0.19-1.00$ & $\begin{array}{l}\text { Antibiotics reduced risk of repeat positive } \\
\text { urine culture. }\end{array}$ \\
\hline $\begin{array}{l}\text { Mori et al (2009) } \\
\text { [56] }\end{array}$ & $8(677)$ & No & RR: 0.96 & $0.69-1.32$ & $\begin{array}{l}\text { No difference in recurrence of } \\
\text { symptomatic UTI or in incidence of } \\
\text { new/progressive renal scarring. }\end{array}$ \\
\hline $\begin{array}{l}\text { Dai et al (2010) } \\
\text { [57] }\end{array}$ & $11(2,046)$ & No & RR: 0.83 & $0.66-1.05$ & No effect on incidence of recurrent UTI. \\
\hline $\begin{array}{l}\text { Williams and Craig } \\
\text { (2011) [58] }\end{array}$ & $5(1,069)$ & Yes & RR: 0.68 & $0.48-0.95$ & $\begin{array}{l}\text { Antibiotics reduced risk of repeat } \\
\text { symptomatic UTI but the benefit is } \\
\text { small. }\end{array}$ \\
\hline $\begin{array}{l}\text { Wang et al (2015) } \\
{[17]^{a}}\end{array}$ & $8(1,594)$ & $\begin{array}{l}\text { Yes (for recurrent UTI, not } \\
\text { for renal scarring) }\end{array}$ & OR: 0.63 & $0.42-0.96$ & $\begin{array}{l}\text { Increase antibiotic resistant } \\
\text { uropathogens, OR: } 8.75 \text {. No reduction } \\
\text { in renal scarring. }\end{array}$ \\
\hline \multirow[t]{2}{*}{$\begin{array}{l}\text { de Bessa et al } \\
(2015)[59]^{\text {a }}\end{array}$} & $7(1,593)$ & $\begin{array}{l}\text { Without RIVUR study: yes, } \\
\text { only for VUR grade } 3,4\end{array}$ & $\begin{array}{l}\text { RR: } 0.75 \text { (VUR 3, 4) } \\
\text { RR: } 0.87 \text { (VUR 1, 2) }\end{array}$ & $\begin{array}{l}0.56-1.01 \\
0.42-1.82\end{array}$ & \\
\hline & & $\begin{array}{l}\text { With RIVUR study: yes, for } \\
\text { all VUR grades }\end{array}$ & $\begin{array}{l}\text { RR: } 0.72(\text { VUR 3, 4) } \\
\text { RR: } 0.51 \text { (VUR 1, 2) }\end{array}$ & $\begin{array}{l}0.56-0.92 \\
0.32-0.79\end{array}$ & \\
\hline $\begin{array}{l}\text { Hewitt et al (2017) } \\
{[60]^{a}}\end{array}$ & $7(1,427)$ & No & RR: 0.83 & $0.55-1.26$ & $\begin{array}{l}\text { No influence of antibiotic prophylaxis in } \\
\text { preventing renal scarring (including } \\
\text { those with VUR) }\end{array}$ \\
\hline
\end{tabular}

RIVUR, Randomized Intervention for Children with Vesicoureteral Reflux; RR, relative risk; UTI, urinary tract infection; VUR, vesicoureteral reflex.

${ }^{a}$ Denote that RIVUR trial was included in their analysis.

of the efficacy of CAP for preventing recurrent UTIs. In 2011, Williams and Craig [58] performed a systematic review including data from 12 clinical trials containing 6 studies that compared results with CAP and placebo/ no treatment. When data from all clinical studies were examined, CAP did not appear to reduce recurrent UTIs (RR, 0.75; 95\% CI, 0.36-1.53); however, when data from studies with low risk of bias were included, CAP appeared to significantly reduce recurrent UTIs (RR, 0.68; 95\% CI, 0.48-0.95). Also, the efficacy of CAP was similar among children with or without VUR. Pooled data from 3 studies indicated increased risk for emergence of multidrugresistant bacteria in children who received CAP (RR, 2.4; 95\% CI, 0.62-9.26) [58].

In 2015, two systematic reviews and meta-analyses that included data from the RIVUR trial were published
$[17,59]$. Inclusion of data from the large RIVUR trial shifted results towards significant efficacy of CAP compared with placebo in preventing recurring febrile UTIs (OR, 0.63; 95\% CI, 0.42-0.96) in children irrespective of concurrent high grade VUR. The studies also showed increased risk of developing an antibiotic-resistant infection in children on CAP (OR, 8.75; 95\% CI, 3.52-21.73) $[17,59]$. Another systematic review on the efficacy of CAP for preventing renal scarring was published in 2017 [60]. As discussed above, the results indicated no influence of CAP for prevention of renal scarring (RR, 0.83; 95\% CI, 0.55-1.26). A sub-analysis limited to children with VUR indicated similar results ( $R R, 0.79 ; 95 \% \mathrm{CI}, 0.51-1.24$ ) [60]. Recently, results from a systematic review and metaanalysis revealed that CAP may reduce the risk of recurrent symptomatic UTI in children who have had one or 
more previous UTIs, but the benefit may be small (RR, 0.75; 95\% CI, 0.28-1.98). Additionally, a two-and-halffold higher threat of developing an antibiotic-resistant infection in children receiving CAP (RR, 2.40; 95\% CI, $0.62-9.26)$ was reported [61].

\section{Antibiotic options for CAP}

When indicated, CAP can be administered from 6 months to 12 months using narrow-spectrum antibiotics, such as nitrofurantoin (at a dose of $1 \mathrm{mg} / \mathrm{kg} / \mathrm{d}$ ) or TMPSMX (at a dose of $2 \mathrm{mg} / \mathrm{kg} / \mathrm{d}$ of TMP). These antibiotics are generally associated with fewer adverse events, less risk of developing multidrug-resistant secondary infections, do not disrupt commensal bowel flora, and are affordable [34,61]. CAP should be stopped or changed if a resistant microorganism is identified in the urine culture of a pediatric patient, even if contamination of urine culture is suspected $[34,61]$. In a pediatric patient with spina bifida and neurogenic bladder, intravesicular aminoglycoside irrigation can be utilized for both treatment and prophylaxis of UTIs, but there is no data on long-term toxicity in pediatric patients [62].

\section{Other adjunct UTI management}

Various studies have reported that cranberry can be used as an adjunct therapy for recurrent UTIs due to the presence of proanthocyanidins, which are believed to be responsible for the antibacterial activity $[63,64]$. Fructose and proanthocyanidins contained in cranberry have been shown to impede in vitro adhesion of $E$. coli fimbriae to urinary tract epithelial cell lines in a dosedependent manner $[65,66]$. However, clinical pharmacologic studies have shown that the level of proanthocyanidins in urine samples was below the levels shown to be effective in in vitro studies. Thus, an alternative proposed mechanism is that proanthocyanidins promote the growth of non-virulent bacterial strains to indirectly prevent growth of the virulent bacteria commonly involved in UTIs [67]. Clinical studies have reported contradictory results on the benefit of cranberry in preventing UTIs. Results of a RCT indicated no difference in the number of children with recurrent UTIs who received cranberry juice compared with placebo; however, cranberry juice was reported to help limit recurrences and the amount of antibiotic used per patient. Results from another RCT indicated that cranberry juice successfully reduced the occurrence of recurrent UTIs over a year compared with placebo treatment $[68,69]$.

Several studies have reported that probiotics, the normal bacterial flora that usually colonize the human gut, can be used to prevent recurrent UTIs. A RCT involving treatment with probiotic Lactobacillus acidophilus and TMP-SMX showed that there was not much of a difference between the probiotic and TMP-SMX groups (18.3 versus 21.6) for preventing recurrent UTIs. However, results from another RCT indicated that a combination of probiotic with nitrofurantoin significantly lowered the occurrence of recurrent UTIs compared with nitrofurantoin alone $[70,71]$.

Results from a small clinical investigation suggested that weekly intravesical injection of hyaluronic acid (prevents bacterial adherence to inner epithelial lining of urinary tract) for 4 weeks effectively reduced the incidence of recurrent UTIs in children [72]. Large, well-designed RCTs are required to draw robust conclusions about the efficacy of cranberry juice, probiotics, or hyaluronic acid for preventing UTIs.

\section{Conclusion}

No conclusive evidence can be drawn from available clinical data in favor of CAP for preventing renal scarring in children with first or second febrile UTI with or without VUR. Additional well designed studies may lead to different conclusions in the future. Currently available clinical data supports 'selective' use of CAP for preventing recurrent UTI or reducing the number of UTIs and subsequent renal scarring in certain high-risk pediatric patients with anatomic abnormality of the urinary system. Efficient antibiotic stewardship and careful selection of appropriate antibiotics based on culture results, antibiotic susceptibility, and geographic location/local guidelines is vital for treating UTIs in children and reducing the emergence of multidrug-resistant infections.

\section{Conflicts of interest}

All authors have no conflicts of interest to declare. 


\section{Authors' contributions}

Sarah S. Alsubaie participated in conception, data collection, analysis and wrote the manuscript. Mazin A. Barry participated in analysis and interpretation of the data. All authors read and approved the final version.

\section{References}

[1] Peters CA, Skoog SJ, Arant BS Jr, et al. Summary of the AUA guideline on management of primary vesicoureteral reflux in children. J Urol 2010;184:1134-1144.

[2] Subcommittee on Urinary Tract Infection, Steering Committee on Quality Improvement and Management, Roberts KB. Urinary tract infection: clinical practice guideline for the diagnosis and management of the initial UTI in febrile infants and children 2 to 24 months. Pediatrics 2011;128:595-610.

[3] Greenfield SP, Cheng E, DeFoor W, et al. Vesicoureteral reflux and antibiotic prophylaxis: why cohorts and methodologies matter. J Urol 2016;196:1238-1243.

[4] Chang SL, Shortliffe LD. Pediatric urinary tract infections. Pediatr Clin North Am 2006;53:379-400, vi.

[5] O'Brien K, Stanton N, Edwards A, Hood K, Butler CC. Prevalence of urinary tract infection (UTI) in sequential acutely unwell children presenting in primary care: exploratory study. Scand J Prim Health Care 2011;29:19-22.

[6] Zorc JJ, Levine DA, Platt SL, et al.; Multicenter RSV-SBI Study Group of the Pediatric Emergency Medicine Collaborative Research Committee of the American Academy of Pediatrics. Clinical and demographic factors associated with urinary tract infection in young febrile infants. Pediatrics 2005;116:644-648.

[7] Hellström A, Hanson E, Hansson S, Hjälmås K, Jodal U. Association between urinary symptoms at 7 years old and previous urinary tract infection. Arch Dis Child 1991;66:232234.

[8] Shaikh N, Hoberman A. Urinary tract infections in children: epidemiology and risk factors. In: Edwards MS, Mattoo TK, eds. UpToDate, Waltham, MA, 2019.

[9] Shaikh N, Morone NE, Bost JE, Farrell MH. Prevalence of urinary tract infection in childhood: a meta-analysis. Pediatr Infect Dis J 2008;27:302-308.

[10] Kanellopoulos TA, Salakos C, Spiliopoulou I, Ellina A, Nikolakopoulou NM, Papanastasiou DA. First urinary tract infection in neonates, infants and young children: a com- parative study. Pediatr Nephrol 2006;21:1131-1137.

[11] Nuutinen M, Uhari M. Recurrence and follow-up after urinary tract infection under the age of 1 year. Pediatr Nephrol 2001;16:69-72.

[12] Jodal U. The natural history of bacteriuria in childhood. Infect Dis Clin North Am 1987;1:713-729.

[13] National Collaborating Centre for Women's and Children's Health (UK). Urinary tract infection in children: diagnosis, treatment and long-term management. London: RCOG Press; 2007.

[14] Normand IC, Smellie JM. Prolonged maintenance chemotherapy in the management of urinary infection in childhood. Br Med J 1965;1:1023-1026.

[15] Smellie JM, Grüneberg RN, Leakey A, Atkin WS. Long-term low-dose co-trimoxazole in prophylaxis of childhood urinary tract infection: clinical aspects. Br Med J 1976;2:203206.

[16] National Institute for Health and Care Excellence. Urinary tract infection (recurrent): antimicrobial prescribing [Internet]. London (UK): National Institute for Health and Care Excellence, 2018 [cited 2018 Oct 31]. Available from: www. nice.org.uk/guidance/ng112.

[17] Wang HH, Gbadegesin RA, Foreman JW, et al. Efficacy of antibiotic prophylaxis in children with vesicoureteral reflux: systematic review and meta-analysis. J Urol 2015;193: 963-969.

[18] Hari P, Hari S, Sinha A, et al. Antibiotic prophylaxis in the management of vesicoureteric reflux: a randomized double-blind placebo-controlled trial. Pediatr Nephrol 2015; 30:479-486.

[19] Ladhani S, Gransden W. Increasing antibiotic resistance among urinary tract isolates. Arch Dis Child 2003;88:444445.

[20] Saltoglu N, Karali R, Yemisen M, et al. Comparison of community-onset healthcare-associated and hospital-acquired urinary infections caused by extended-spectrum betalactamase-producing Escherichia coli and antimicrobial activities. Int J Clin Pract 2015;69:766-770.

[21] Conway PH, Cnaan A, Zaoutis T, Henry BV, Grundmeier RW, Keren R. Recurrent urinary tract infections in children: risk factors and association with prophylactic antimicrobials. JAMA 2007;298:179-186.

[22] Craig JC, Simpson JM, Williams GJ, et al.; Prevention of Recurrent Urinary Tract Infection in Children with Vesicoureteric Reflux and Normal Renal Tracts (PRIVENT) Investigators. Antibiotic prophylaxis and recurrent urinary tract 
infection in children. N Engl J Med 2009;361:1748-1759.

[23] Montini G, Rigon L, Zucchetta P, et al.; IRIS Group. Prophylaxis after first febrile urinary tract infection in children? A multicenter, randomized, controlled, noninferiority trial. Pediatrics 2008;122:1064-1071.

[24] Gaspari RJ, Dickson E, Karlowsky J, Doern G. Antibiotic resistance trends in paediatric uropathogens. Int J Antimicrob Agents 2005;26:267-271.

[25] Jakovljević E, Ilić K, Jelesić Z, Konstantinidis G. A one-year prospective study on the antibiotic resistance of E. coli strains isolated in urinary specimens of children hospitalized at the University Pediatric Medical Center in Novi Sad, Serbia. Infection 2013;41:1111-1119.

[26] Allen UD, MacDonald N, Fuite L, Chan F, Stephens D. Risk factors for resistance to "first-line" antimicrobials among urinary tract isolates of Escherichia coli in children. CMAJ 1999;160:1436-1440.

[27] Saperston KN, Shapiro DJ, Hersh AL, Copp HL. A comparison of inpatient versus outpatient resistance patterns of pediatric urinary tract infection. J Urol 2014;191(5 Suppl):1608-1613.

[28] Garraffo A, Marguet C, Checoury A, et al. Urinary tract infections in hospital pediatrics: many previous antibiotherapy and antibiotics resistance, including fluoroquinolones. Med Mal Infect 2014;44:63-68.

[29] Ismaili K, Lolin K, Damry N, Alexander M, Lepage P, Hall M. Febrile urinary tract infections in 0- to 3-month-old infants: a prospective follow-up study. J Pediatr 2011;158:9194.

[30] Paschke AA, Zaoutis T, Conway PH, Xie D, Keren R. Previous antimicrobial exposure is associated with drug-resistant urinary tract infections in children. Pediatrics 2010; 125:664-672.

[31] Fan NC, Chen HH, Chen CL, et al. Rise of communityonset urinary tract infection caused by extended-spectrum $\beta$-lactamase-producing Escherichia coli in children. $J$ Microbiol Immunol Infect 2014;47:399-405.

[32] Tratselas A, Iosifidis E, Ioannidou M, et al. Outcome of urinary tract infections caused by extended spectrum $\beta$-lactamase-producing Enterobacteriaceae in children. Pediatr Infect Dis J 2011;30:707-710.

[33] Thabit AK, Crandon JL, Nicolau DP. Antimicrobial resistance: impact on clinical and economic outcomes and the need for new antimicrobials. Expert Opin Pharmacother 2015;16:159-177.

[34] Selekman RE, Shapiro DJ, Boscardin J, et al. Uropathogen resistance and antibiotic prophylaxis: a meta-analysis. Pediatrics 2018;142:e20180119.

[35] Copp HL, Halpern MS, Maldonado Y, Shortliffe LD. Trends in hospitalization for pediatric pyelonephritis: a population based study of California from 1985 to 2006. J Urol 2011; 186:1028-1034.

[36] Mohammad-Jafari H, Saffar MJ, Nemate I, Saffar H, Khalilian AR. Increasing antibiotic resistance among uropathogens isolated during years 2006-2009: impact on the empirical management. Int Braz J Urol 2012;38:25-32.

[37] Al-Mardeni RI, Batarseh A, Omaish L, Shraideh M, Batarseh B, Unis N. Empirical treatment for pediatric urinary tract infection and resistance patterns of uropathogens, in Queen Alia hospital and prince A'Isha military center--Jordan. Saudi J Kidney Dis Transpl 2009;20:135139.

[38] Doré-Bergeron MJ, Gauthier M, Chevalier I, McManus B, Tapiero B, Lebrun S. Urinary tract infections in 1- to 3-month-old infants: ambulatory treatment with intravenous antibiotics. Pediatrics 2009;124:16-22.

[39] Sakran W, Smolkin V, Odetalla A, Halevy R, Koren A. Community-acquired urinary tract infection in hospitalized children: etiology and antimicrobial resistance. A comparison between first episode and recurrent infection. Clin Pediatr (Phila) 2015;54:479-483.

[40] Wang J, He L, Sha J, et al. Etiology and antimicrobial resistance patterns in pediatric urinary tract infection. Pediatr Int 2018;60:418-422.

[41] Erol B, Culpan M, Caskurlu H, et al. Changes in antimicrobial resistance and demographics of UTIs in pediatric patients in a single institution over a 6-year period. J Pediatr Urol 2018;14:176.e1-176.e5.

[42] Yoo YM, Park BS, Lee SY, Park KJ, Jung HJ, Pai KS. An epidemiologic study on hosts and pathogens of urinary tract infection in urban children of Korea (2012-2017). Child Kidney Dis 2019;23:29-35.

[43] Vazouras K, Velali K, Tassiou I, et al. Treatment and antimicrobial resistance in children with urinary tract infections. J Glob Antimicrob Resist 2019 Jun 25 [Epub]. Doi: 10.1016/ j.jgar.2019.06.016.

[44] Copp HL, Shapiro DJ, Hersh AL. National ambulatory antibiotic prescribing patterns for pediatric urinary tract infection, 1998-2007. Pediatrics 2011;127:1027-1033.

[45] Jerardi KE, Auger KA, Shah SS, et al. Discordant antibiotic therapy and length of stay in children hospitalized for urinary tract infection. J Hosp Med 2012;7:622-627. 
[46] Brandström P, Jodal U, Sillén U, Hansson S. The Swedish reflux trial: review of a randomized, controlled trial in children with dilating vesicoureteral reflux. J Pediatr Urol 2011; 7:594-600.

[47] Garin EH, Olavarria F, Garcia Nieto V, Valenciano B, Campos A, Young L. Clinical significance of primary vesicoureteral reflux and urinary antibiotic prophylaxis after acute pyelonephritis: a multicenter, randomized, controlled study. Pediatrics 2006;117:626-632.

[48] Pennesi M, Travan L, Peratoner L, et al.; North East Italy Prophylaxis in VUR study group. Is antibiotic prophylaxis in children with vesicoureteral reflux effective in preventing pyelonephritis and renal scars? A randomized, controlled trial. Pediatrics 2008;121:e1489-e1494.

[49] Roussey-Kesler G, Gadjos V, Idres N, et al. Antibiotic prophylaxis for the prevention of recurrent urinary tract infection in children with low grade vesicoureteral reflux: results from a prospective randomized study. J Urol 2008;179:674679.

[50] Hoberman A, Greenfield SP, Mattoo TK, et al.; RIVUR Trial Investigators. Antimicrobial prophylaxis for children with vesicoureteral reflux. N Engl J Med 2014;370:2367-2376.

[51] Wang ZT, Wehbi E, Alam Y, Khoury A. A reanalysis of the RIVUR trial using a risk classification system. J Urol 2018; 199:1608-1614.

[52] Copp HL, Nelson CP, Shortliffe LD, Lai J, Saigal CS, Kennedy WA; Urologic Diseases in America Project. Compliance with antibiotic prophylaxis in children with vesicoureteral reflux: results from a national pharmacy claims database. $J$ Urol 2010;183:1994-1999.

[53] Mattoo TK, Chesney RW, Greenfield SP, et al.; RIVUR Trial Investigators. Renal scarring in the Randomized Intervention for Children with Vesicoureteral Reflux (RIVUR) trial. Clin J Am Soc Nephrol 2016;11:54-61.

[54] Williams GJ, Lee A, Craig JC. Long-term antibiotics for preventing recurrent urinary tract infection in children. $\mathrm{Co}$ chrane Database Syst Rev 2001;(4):CD001534.

[55] Williams GJ, Wei L, Lee A, Craig JC. Long-term antibiotics for preventing recurrent urinary tract infection in children. Cochrane Database Syst Rev 2006;(3):CD001534.

[56] Mori R, Fitzgerald A, Williams C, Tullus K, Verrier-Jones K, Lakhanpaul M. Antibiotic prophylaxis for children at risk of developing urinary tract infection: a systematic review. Acta Paediatr 2009;98:1781-1786.

[57] Dai B, Liu Y, Jia J, Mei C. Long-term antibiotics for the prevention of recurrent urinary tract infection in children: a systematic review and meta-analysis. Arch Dis Child 2010; 95:499-508.

[58] Williams G, Craig JC. Long-term antibiotics for preventing recurrent urinary tract infection in children. Cochrane Database Syst Rev 2011;(3):CD001534.

[59] de Bessa J Jr, de Carvalho Mrad FC, Mendes EF, et al. Antibiotic prophylaxis for prevention of febrile urinary tract infections in children with vesicoureteral reflux: a metaanalysis of randomized, controlled trials comparing dilated to nondilated vesicoureteral reflux. J Urol 2015;193(5 Suppl):1772-1777.

[60] Hewitt IK, Pennesi M, Morello W, Ronfani L, Montini G. Antibiotic prophylaxis for urinary tract infection-related renal scarring: a systematic review. Pediatrics 2017;139: e20163145.

[61] Williams G, Craig JC. Long-term antibiotics for preventing recurrent urinary tract infection in children. Cochrane Database Syst Rev 2019;4:CD001534.

[62] Huynh D, Morgan JA. Use of intravesicular amikacin irrigations for the treatment and prophylaxis of urinary tract infections in a patient with spina bifida and neurogenic bladder: a case report. J Pediatr Pharmacol Ther 2011;16:102107.

[63] Howell AB, Reed JD, Krueger CG, Winterbottom R, Cunningham DG, Leahy M. A-type cranberry proanthocyanidins and uropathogenic bacterial anti-adhesion activity. Phytochemistry 2005;66:2281-2291.

[64] Gupta K, Chou MY, Howell A, Wobbe C, Grady R, Stapleton AE. Cranberry products inhibit adherence of $\mathrm{p}$-fimbriated Escherichia coli to primary cultured bladder and vaginal epithelial cells. J Urol 2007;177:2357-2360.

[65] Foo LY, Lu Y, Howell AB, Vorsa N. The structure of cranberry proanthocyanidins which inhibit adherence of uropathogenic P-fimbriated Escherichia coli in vitro. Phytochemistry 2000;54:173-181.

[66] Howell AB, Foxman B. Cranberry juice and adhesion of antibiotic-resistant uropathogens. JAMA 2002;287:3082-3083.

[67] Valentova K, Stejskal D, Bednar P, et al. Biosafety, antioxidant status, and metabolites in urine after consumption of dried cranberry juice in healthy women: a pilot doubleblind placebo-controlled trial. J Agric Food Chem 2007;55: 3217-3224.

[68] Salo J, Uhari M, Helminen M, et al. Cranberry juice for the prevention of recurrences of urinary tract infections in children: a randomized placebo-controlled trial. Clin Infect Dis 2012;54:340-346. 
[69] Afshar K, Stothers L, Scott H, MacNeily AE. Cranberry juice for the prevention of pediatric urinary tract infection: a randomized controlled trial. J Urol 2012;188(4 Suppl):1584-1587.

[70] Lee SJ, Shim YH, Cho SJ, Lee JW. Probiotics prophylaxis in children with persistent primary vesicoureteral reflux. Pediatr Nephrol 2007;22:1315-1320.

[71] Mohseni MJ, Aryan Z, Emamzadeh-Fard S, et al. Combi- nation of probiotics and antibiotics in the prevention of recurrent urinary tract infection in children. Iran J Pediatr 2013;23:430-438.

[72] Fidan K, Büyükkaragöz B, Özen O, Demirogullari B, Söylemezoglu O.The use of intravesical hyaluronic acid for recurrent urinary tract infections in children: a case-series study. Ren Fail 2015;37:354-358. 